Published with Open Access at Journal BiNET

Vol. 03, Issue 01: 140-147

International

Journal BiNET

Journal of Business, Management and Social Research

Journal Home: www.journalbinet.com/ijbmsr-journal.html

\title{
Farmer empowerment through development of ecotecnopreneurship by managing mix farming based on social capital
}

\section{Imam Santosa ${ }^{\mathrm{a}}$ and Agus Suyanto ${ }^{\mathrm{b}}$}

aSociology Department, Faculty of Social and Political Sciences, Jenderal Soedirman University, Indonesia

b Agrotechnology Department, Faculty of Agriculture, Jenderal Soedirman University, Indonesia

\begin{abstract}
This research aimed to study empowerment of farmers through development of ecotechnopreneurship behavior by managing mix farming based on the social capital. Research method used a case study with qualitative and quantitative approach. Locations of research are set intentionally in the Agrotourism Zone of Karangreja District, Purbalingga Regency and Agrotourism Zone Baturaden District, Banyumas Regency, Central Java Province. Based on survey results revealed that social capital have important functions in the process of empowerment of farmers through development of ecotechnopreneurship behavior in managing mix farming. Third element of social capital, that has studied closely related to mutual trust, cooperation networking, social norms and institutitons in the community in two agro zone. However, in some productive activity there is domination of different functions among the three elements.
\end{abstract}

Key Words: Farmer empowerment, Development, Ecotechnopreneurship and Social capital

Please cite this article as: Santosa, I. \& Suyanto, A. (2016). Farmer empowerment through development of ecotecnopreneurship by managing mix farming based on social capital. International Journal of Business, Management and Social Research, 03(01), 140-147.

This article is distributed under terms of a Creative Common Attribution 4.0 International License.

\section{Introduction}

Farmer empowerment is still urgently carried out by various parties seriously. Empowerment should be interpreted as a process or mechanism that drives the active participation of individuals, groups and communities to solve their problems themselves. Wrihatnolo and Dwidjowijoto (2007) describe that empowerment: empowerment will become the different forms for different people, the empowerment will be different for different contexts and empowerment fluctuate or change over time. Santosa et al. (2006) found farmers empowerment effective efforts is driven through the transmission of social capital in the development of productive diversification. Improving the ability of farming communities in the management of productive and creative effort is one of strategic needs in order to alleviate poverty. Through development of business diversification, problems of farming communities which are vulnerability of plants and scarcity of production factors in dry season can be resolved effectively. Such circumstances like that are also found in the farming community in the area of agrotourism. Threat of job loss due to loss of arable land in farming communities in the area of agro-turns can be solved by increasing awareness and the ability to utilize the remaining land for productive business environmentally friendly. This statement is supported by the results of research Santoso et al. (2012) which showed that one type of productive enterprises in accordance with the problems and the 
state of society, especially farmers in the region developed mix farming by utilizing local resources. Nevertheless, the diffusion process of mix farming turns to face several obstacles. Constraints that have a strong influence among others related to limitations in terms of: entrepreneurship, partnerships, adoption of technology, market access, price and environmental consciousness as well. McClelland also confirmed to pursue success in the economic field, including success in farming, and it can be happened when someone in a social group feel motivated (need for achievement motivation) to have an entrepreneurial spirit (Santosa, 2004). Farmer empowerment, indeed, is not a simple thing, but it's more complex because it involves various interrelated components including the readiness of local resources. Research of Santosa et al. (2014) found that a social reality that the empowerment of farming communities through the management of mixed farming businesses can be encouraged by the change of behavior in ecotechnopreneurship and its social capital. Goal of this research is to study the farmer community empowerment through ecotechnopreneurship behavior change in managing the mix farming with social capital base.

\section{Materials and Methods}

Determination of the location of the research done on purpose in two agro zone, namely Baturaden Agro Zone, Banyumas Regency and Agro Zone of Karangreja, Purbalingga Regency, Central Java Province. Method used is a case study with a qualitative and quantitative approach. Subject of the study include overall community members residing in the two sites and pattern of living as farmers of mix farming. Informants of this research are determined by purposive sampling technique. The number of informants representing Karangreja Agro Zone 22 and Baturaden Agro Zone of 24 people. Thus, overall number of informants of this research was 46 people. Types of data needed in this study are primary and secondary data. Data collection activity using the technique: Focus Group Discussion (FGD), in-depth interviews, consultative interviews and participating observation. Secondary data was collected using documentation analysis techniques. Data were analyzed with the Interactive Model of Analysis (Miles and Huberman, 1991).

\section{Results and Discussion}

Social capital is a set of informal values or norms that allow each other to cooperate. Social capital serves as the glue in structure of social structure (Fukuyama, 2000). Area of this research is Baturaden and Karangreja, both of them can be classified in rural area. This community feels that social capital is a part of their actual life. Based on the observation of social condition of rural communities, Baturaden and Karangreja appeared to have similarities and differences in some aspects. Similarities can be shown on existence of social capital elements and realization in various life movements in managing mix farming by utilizing ecotechnoentrepreneur. Figure 01 shows realization of social capital in some activities informants in Karangreja and Baturaden.

Based on the information shown in Figure 01, the similarities of the realization of the social capital in both groups are about empathy and sympathy towards togetherness of community in activities related to the development of mix farming. The Other circumstances can be seen from community possession tolerance towards other associate with mix farming development both in pre-production, production and post-production process. By the time a farmer pepper plants affected by pest attack yaws and curling the farmers come to feel it as a threat together that will lead to crop failure. With the existing tolerance, the farmers finally participated actively trying to find information about drugs that effectively control the pest. Realization of the social capital that shows the most noticeable difference in the two groups studied contained informants ability to persuade others to believe that the product resulting from the management of mixed farming enterprises have a certain added value. Informants are able to convince buyers of dealer collectors, the manager of the restaurant, the manager of the hotel or inn, the small traders and tourists that the resulting product mix from farming businesses have added value than make it different with other product. This social reality happened in the SubDistrict of Baturaden. The added value in question can be assurednesses are availability and quality of vegetables, fruits and other products. For a while, the informants of Karangreja still do not have enough confidence in convincing others in offering a product mix farming business. Not infrequently, some informants admit to just let some the season plant in the garden without being harvested as a result of the price plummeted. Another difference that characterizes the realization of the social capital 
in both groups of informants can be observed from the ability to trust the other parties in the interest of the development mix farming with the use ecotechnoentrepreneur.

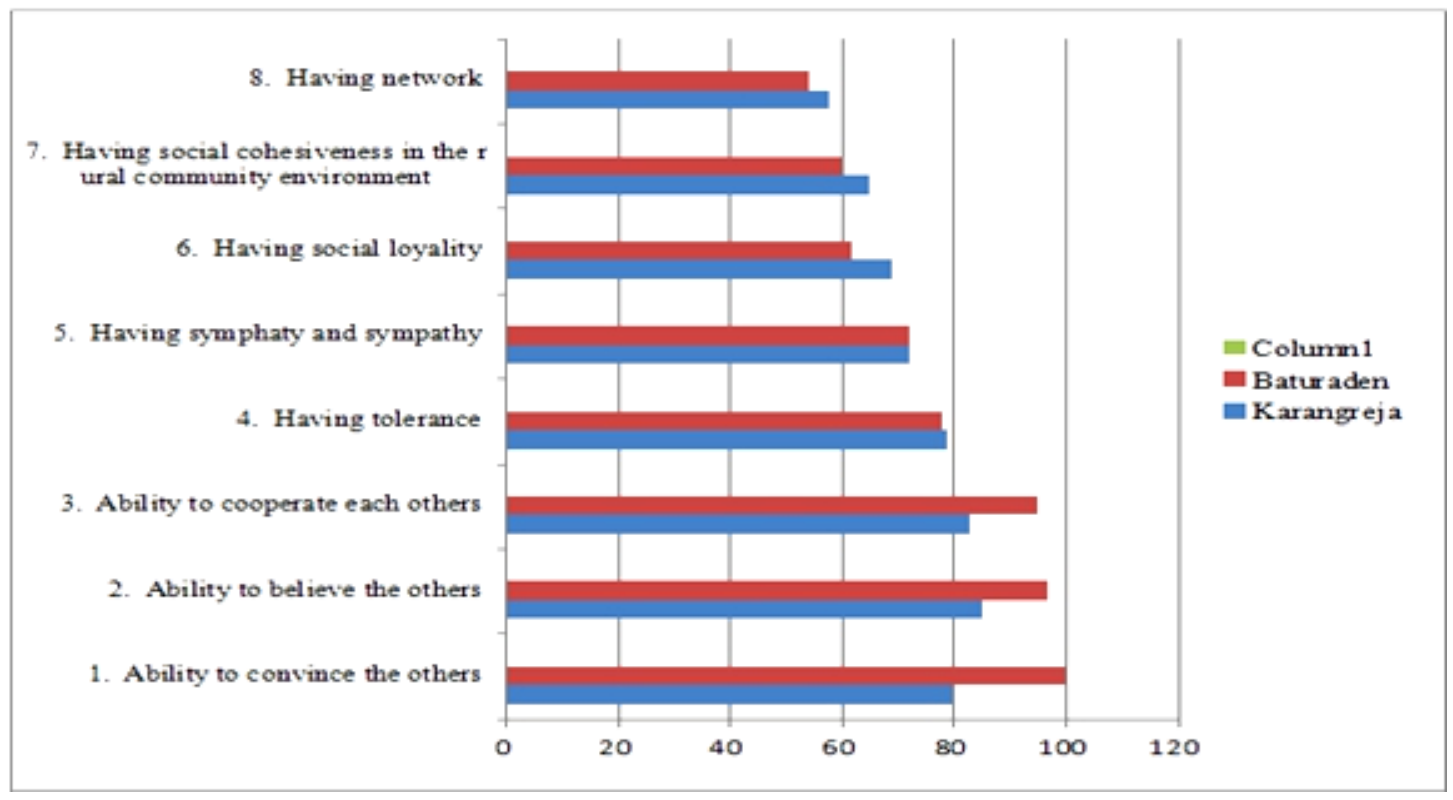

Figure 01. Social capital realization on some activities in managing mix farming in Karangreja and Baturaden (Santosa et al. 2014).

Informants in Karangreja have a cautious attitude and did not immediately believe the other parties, especially who came from the outside of the village in the interest of business development mix farming. The establishment of the association between the informants and other parties who offer innovative agricultural cultivation or packet processing technology business product mix farming requires a role of mediator from among community leaders and village officials as an opinion leader in the village. This situation is closely related to the characteristics Karangreja villagers who still believe in local policy. In contrast to the informant from Baturaden, which on average have characterized as more cosmopolitan individuals with a higher social mobility seem responsive to others who bring new ideas and innovative technologies for the development of mixed farming enterprises. Ability of farmers for getting cooperation with various parties found in the Sub District of Baturaden. On the contrary, informants were not showed too much interest in the Sub District of Karangreja. Responsiveness of farmers in Baturaden are higher than Karangreja in expressing the willingness to cooperate with the various parties that are expected to benefit the development of mixed farming enterprises are managed. Informants dare to bear the risk for the fabric of negotiated cooperation, for example, to open up new marketing channels for a wide range of products produced. Such circumstances influenced the fact that the experience in collaboration owned informant in Baturaden longer than informants in rural Karangreja. According to the informants from rural Baturaden, the average experience of working with various parties already exceeds the span of ten years. The informant from Karangreja has experience cooperate in an interval of 2-8 years. Condition of social capital realization is still different in the two groups. In some cases, the collective bond are strong or weak, but bond collectivity on farmers in Baturaden weakened due to the pressure of commercialization and market penetration is difficult to control. Unlike the case with social reality in Karangreja, collectivity bond is still strongly influence the shared decision-making which is done through deliberation and consensus in the beginning of each technology development activities for mixed farming efficiency. Collectivity ties are different in both groups of informants in turn lead to bond cohesiveness in the social environment of each rural area are not the same. Farmer's community in Karangreja has more social cohesiveness than Baturaden farmers. It can be indicated in some cases of social interaction. People are still emphasizing on personnal relation, mutual understanding as well as cooperation. Ability to establish a cooperation network with various parties in two different study sites. The informants who are in Baturaden has had more extensive cooperation network and longer so that access to price, information, market and technology more adequate than the informant in 
Karangreja. Similarities and differences that characterize mix farming among informants in Karangreja and Baturaden not released from the fact the ability to manage elements of social capital. Each element of it is used informants to meet a variety of needs and interests in managing mix farming. Elements of social capital are often found in various communities include mutual trust (trust), the network (network) and institutional (institutions) that contains values and social norms. Some of the activities that show the behavior of the informants in the utilization of social capital can be clearly shown in Figure 02 .

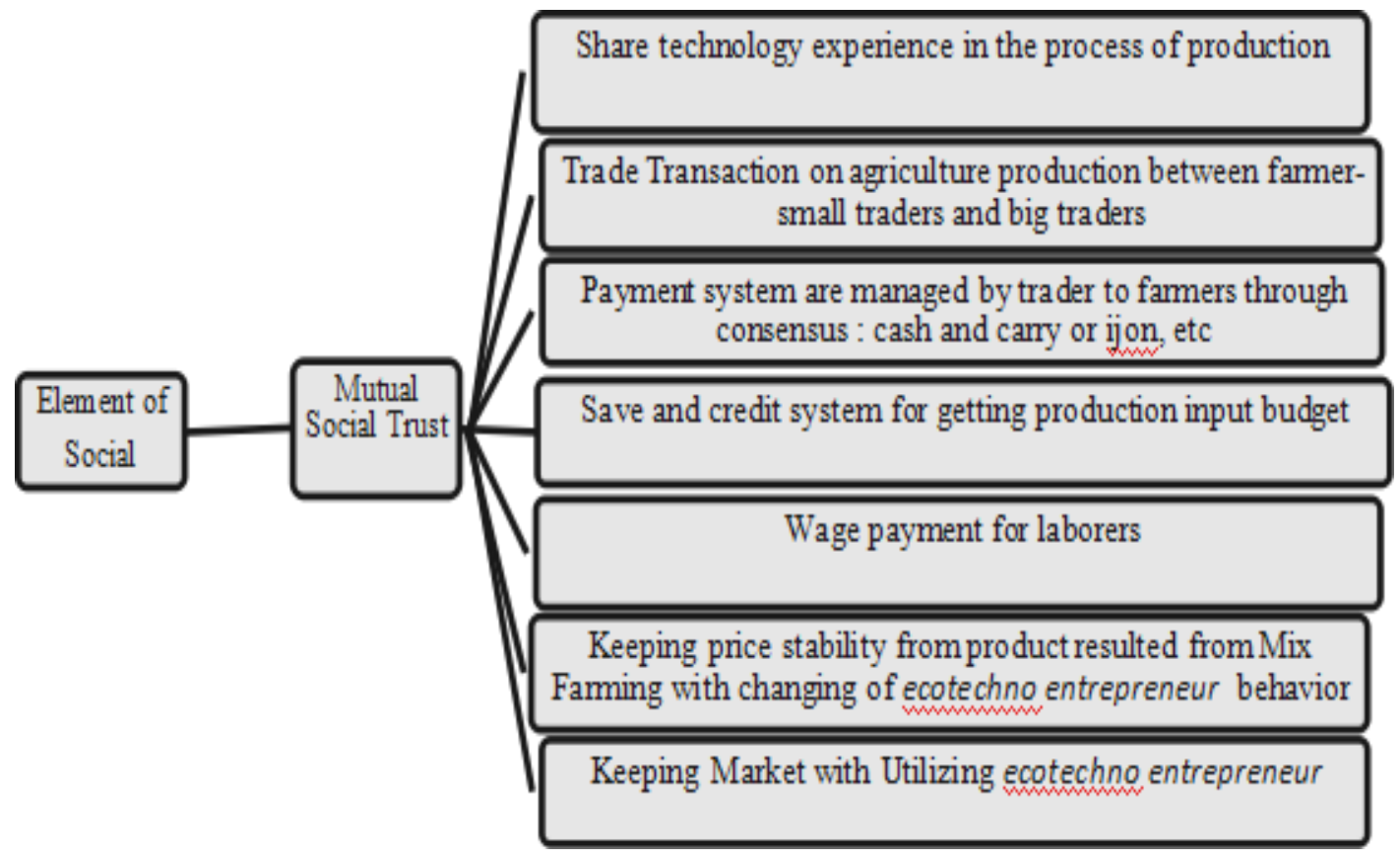

Figure 02. Informant behavior linked with one of the utilization of social capital (Social Trust) (Santosa et al. 2014).

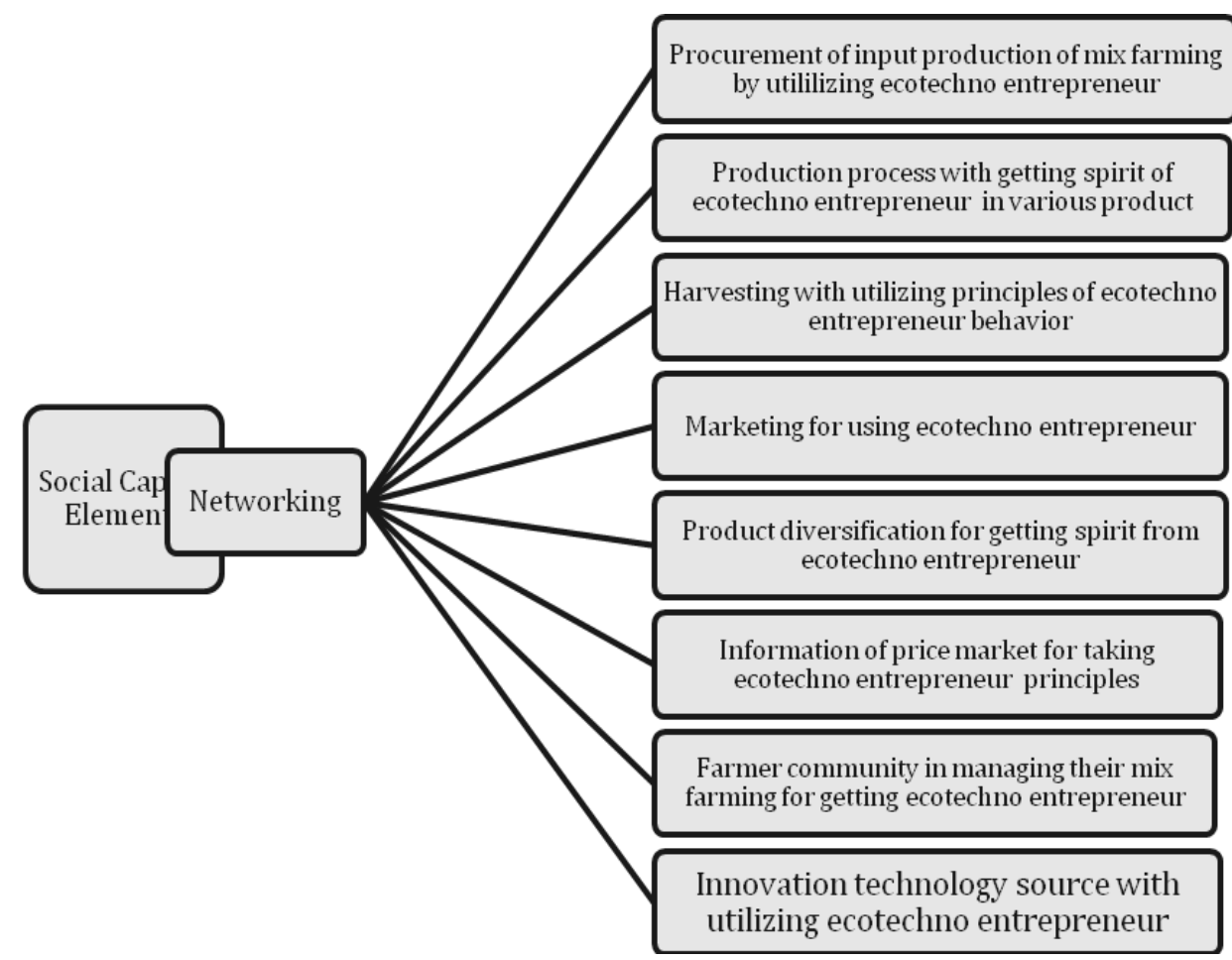

Figure 03. Informant behavior linked with the utilizing social capital (social network) (Santosa et al. 2014). 
Utilization of social capital element of trust is useful for informants in fulfilling relationship that is reciprocity. Polanyi (1968) described the relationship of reciprocity as follows: reciprocity is enormous facilitated by the institutional pattern of symmetry, a frequent feature of organization among non-literate peoples. Forms of reciprocity found in both groups of informants have some of the following characteristics: exchanging reciprocal, no contact and personal relationships, the relationship lasted for a long period and intertwined symmetrical relationship. Informants were not only manage the elements of the social capital of trust (trust) for the benefit of business development mix farming but also has tried to take advantage of other elements of social capital which is networking. Some networks external cooperation with other parties from outside the village have been formed in both groups of informants in Baturaden and Karangreja orientation have focused on the fulfillment of economic interest, especially regarding about the expansion of product markets. According to informants, the establishment of internal cooperation network with those who come from the local village is more motivated by social interests. However, there is no doubt in some of the network's internal cooperation has also been colored by economic motives. In Figure 03 informants observed some behavior in utilizing social capital elements of cooperation networks.

Another element of social capital managed for the development of mix farming is institutional. As described in the previous section that the existence of different types of socio-economic institutional support very meaningful to the informant. Some informant's behavior concerning the management of the institutions of social capital elements listed in Figure 04.

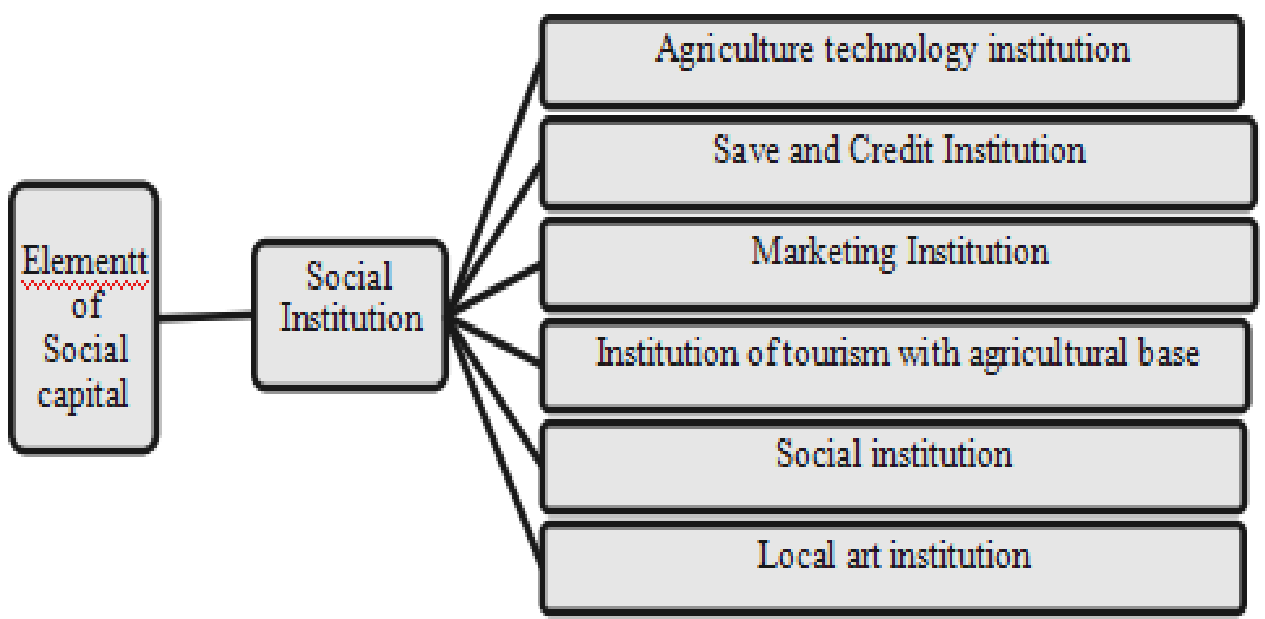

Figure 04. Informant behavior linked with the utilizing social capital (Social Institution) (Santosa et al. 2014).

Generally, all people have social capital. However, reserve levels and the state of social capital among community groups with each other show significant differences that described by Fukuyama (2000) as the "radius of the trust". Values, norms and beliefs that frame the cooperation such as honesty and mutual relationship (reciprocity) found in the informant in Karangreja and Baturaden in the development of potential mix farming disseminated to other community groups to meet the needs of the productive and non-productive. Mechanisms of management of each element of the social capital that benefits the life of the original informant came from the family as the foundation of socialization of values, norms, beliefs that foster the ability of mutual trust, the ability to form a network of cooperation and utilization of institutions for increasing competitiveness in economic activities. The three elements of social capital give different strengths to the informant in developing mix farming with ecotechno based. Differences in the ability to influence the development of the mix farming can be measured from strength domination every element of social capital can be observed in Figure 05. 


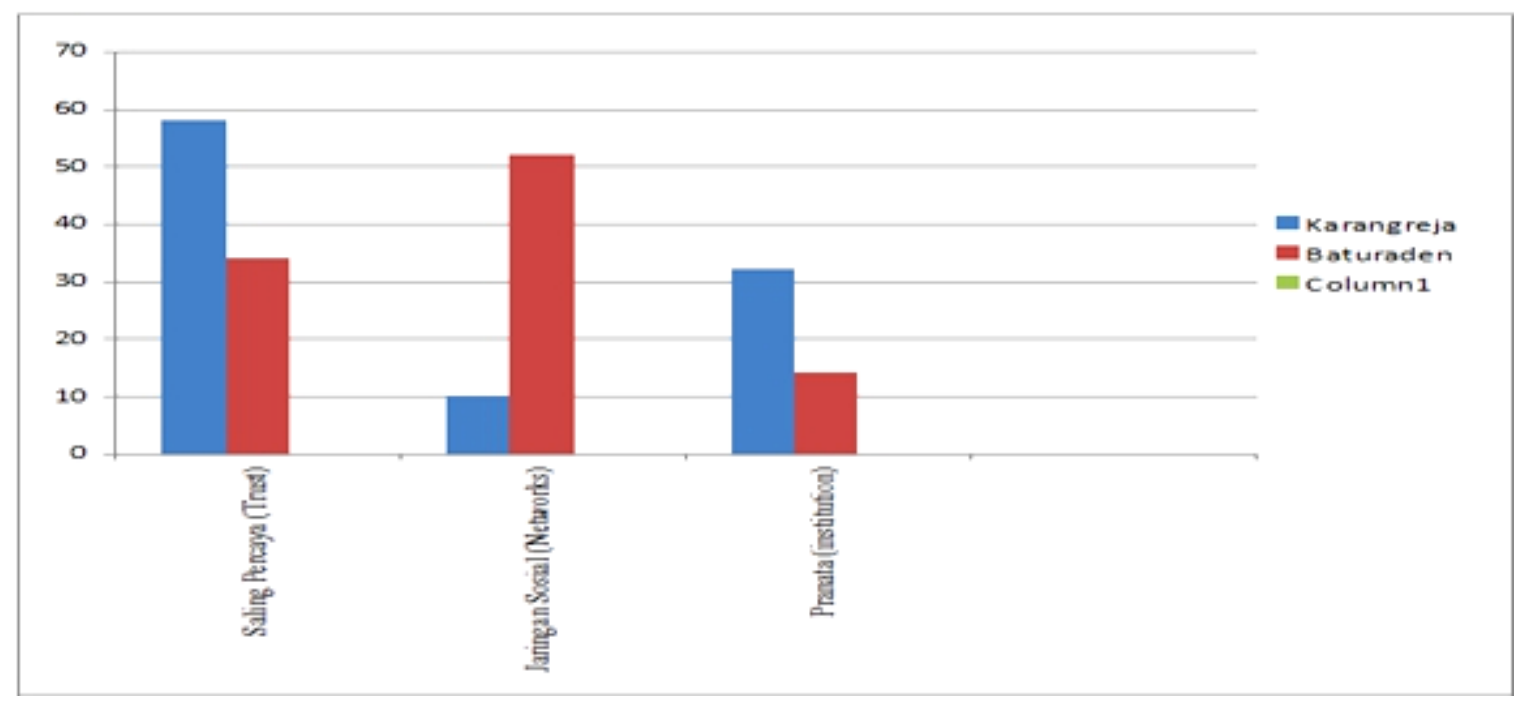

Figure 05. Domination of social capital in farmer empowerment through in managing mix farming for utilizing ecotechnoentrepreneur (Santosa et al. 2014).

Shane and Venkataraman (2000) found that entrepreneurs who have high social capital are more likely to find opportunities that are higher than the entrepreneurs who do not have less or no social capital. This amusement with which dimekukakan previous expert Putnam (2000) came to the conclusion that social capital has the opportunity to have better social networks. Thus it can improve the efficiency of the public in its mission to achieve common prosperity. In the results of the latest study found that there are two roles to be played in any business that is social capital and human capital. This research can be traced from Coleman (1988), which discusses the role of social capital and its influence on school performance, then Nahapiet and Ghoshal (1988), which emphasizes the relationship of social capital and profit organizations. In a wider context, found in the results of research suggested by Davidson and Honig (2003) revealed that social capital is able to reduce poverty. In the context of more specific interest related to this study interesting proposed by Scott (1976), those peasants in Southeast Asia behavior is largely determined by their historical roots. They oriented to the safety first orientation, so they tend less innovation. Of course it is a barrier for peasants to develop. Findings Santosa et al. (2015) to be innovative, because it managed to map where farmers have high levels of entrepreneurship and low and when social capital that can be touched as the entrance to empower farmers.

\section{Conclusion}

Varieties of issues that affect the success of farming in both agro-tourism zones have been discovered. All of these problems have different challenges. It can be classified into social dimension, technological, economic and environmental dimension. In order to optimize the management of mixed farming for Baturaden, trust can help to solve the problem, while the key to solve the hurdles in Zone Karangreja are able to emphasize on social and economic dimension and technology as well in the form of economic and entrepreneurial capacity raising and technology transfer toward to the farmer autonomy. Third element of social capital that has studied is closely related to mutual trust, cooperation networking, social norms and institutions in the community in two agro Zone. However, in some productive activity there is domination of different functions among the three elements. It can be described in the differences from two agro zone above.

\section{Acknowledgements}

Authors are very grateful to DRPM-KEMRISTEKDIKTI for necessary fund provided to this research. Appreciation goes to Ir. Dumasari, M. Si, Dinda Dewi Aisyah and anonymous reviewers for their assistance in manuscript preparation. 


\section{References}

[1]. Coleman, J. (1988). Social capital in the creation of human capital. American Journal of Sociology, 94(S), S95. https://doi.org/10.1086/228943

[2]. Davidson, Per and Honig, Benson L. (2003). The Role of Social and Human Capital among Nascent Entrepreneurs. Journal of Business Venturing, 18 (3), 301-331. https://doi.org/10.1016/S0883-9026(02)00097-6

[3]. Fukuyama, F. (2000). The great discruption. Human natural and the reconstitution of social order. A touchstone book. Published by Simon \& Schuster. New York. London. Toronto. Sidney. Singapore.

[4]. Miles, M. B. \& Huberman, A. M. (1991). Designing Qualitative Research. Mac Graw Hill Company. New York.

[5]. Nahapiet, J. \& Ghoshal, S. D. (1998). Social capital, intellectual capital and the organizational advantage. Academy of Management Review, 23(2), 242.

[6]. Polanyi, K. (1968). Societies and Economic System. In: George Dalton. Primitive, Archaic and Modern Economies, Essays of Karl Polanyi. Beacon Press, Boston.

[7]. Putnam, R. (2000). Boling Alone: The Collapse and Revivial of American Community. New York: Simon and Schuster, Piazza.

[8]. Santosa, I. (2004).Farmers empowerment in the forest outskirt through the development of adaptive behavior. PhD's Dissertation, Bogor Agricultural University, Bogor.

[9]. Santosa, Imam \& Ahmad Iqbal. (2014). Model of Rural Community Empowerment Through The Development of Ecotechno Entrepreneur Behavior on Managing Mix Farming In The Zone of Agro Tourism. Research Report of Jenderal Soedirman University, pp. 18-44.

[10]. Santosa, Imam \& Ahmad Iqbal. (2015). Model of rural community empowerment through the development of ecotechno entrepreneur behavior on managing mix farming in the zone of agro tourism. Research Report of Jenderal Soedirman University (the third phase), pp. 18-35.

[11]. Santosa, Imam \& Pramono (2012). Model of technology aquaponic in managing mix farming for diversification of pattern of living in zone of agro tourism. Research Report of Jenderal Soedirman University, pp. 5-29.

[12]. Santosa, Imam \& Rostikawati, R. (2006). Model of social capital transmission for farming empowerment in the forest outskirt in the development of needlework embroidery enterprise with unique motive design. Siasat - Journal of Social Sciences, (2), 26-32.

[13]. Scott, J. C. (1976). Moral economy of the peasant: Rebellion and subsistence in the Southeast Asia. New Haven and London: Yale University Press.

[14]. Shane, S. \& Venkataraman, S. (2000). The promise of entrepreneourship as a field of research. Academy of Management Review, 25 (1), 217.

[15]. Wrihatnolo, R. R. \& Dwidjowijoto, R. N. (2007). Empowerment management: An introduction. (Practical guide for community empowerment). Elex Media Komputindo, Jakarta.

\section{How to cite this article?}

\section{APA (American Psychological Association)}

Santosa, I. \& Suyanto, A. (2016). Farmer empowerment through development of ecotecnopreneurship on managing mix farming based on social capital. International Journal of Business, Management and Social Research, 03(01), 140-147.

\section{MLA (Modern Language Association)}

Santosa, I. \& Suyanto, A. "Farmer empowerment through tdevelopment of ecotecnopreneurship by managing mix farming based on social capital." International Journal of Business, Management and Social Research, 03.01 (2016): 140-147.

\section{Chicago/Turabian}

Santosa, I. \& Suyanto, A. "Farmer empowerment through development of ecotecnopreneurship by managing mix farming based on social capital." International Journal of Business, Management and Social Research, 03, no. 01 (2016): 140-147. 